\title{
ORAL POTENTIALLY MALIGNANT DISORDERS ASSOCIATED WITH BETEL QUID CHEWING HABIT IN SAMOSIR ISLAND, NORTH SUMATRA INDONESIA
}

\author{
(KELAINAN MUKOSA MULUT BERPOTENSI MALIGNA YANG DIHUBUNGKAN DENGAN \\ KEBIASAAN MENYIRIH DI PULAU SAMOSIR, SUMATERA UTARA INDONESIA)
}

\author{
Indri Lubis", Ameta Primasari**, Sayuti Hasibuan* \\ * Departemen Ilmu Penyakit Mulut FKG USU \\ ${ }^{* *}$ Departemen Biologi Oral FKG USU \\ jln Alumni No.2 Kampus USU Medan 20155 \\ E-mail : indrilubis83@gmail.com
}

\begin{abstract}
Oral potentially malignant disorders have been associated with a betel quid chewing habit. To date, betel quid chewing has a major social and cultural role in the society of Samosir Island, North Sumatra, Indonesia. The purpose of the present study was to evaluate the occurrence of oral potentially malignant disorders associated with the habit of betel quid chewing in the society of Samosir Island, North Sumatra, Indonesia. This case-control study was conducted on all betel quid chewers in the working area of the Ambarita Public Health Centre in Samosir Regency, North Sumatra, Indonesia. All subjects were examined clinically for the presence of any oral lesions and interviewed for their betel quid chewing habit. Chi-square and Fisher's exact tests were used to analyze the relationship between variables. Among the 51 subjects recruited in the study, 28 subjects suffered from oral potentially malignant disorders who had oral potentially malignant disorders such as submucous fibrosis and/or leukoplakia (the case group) whereas 23 subjects showed no clinically detectable oral potentially malignant disorders (the control group). An increased risk of oral potentially malignant disorders was associated with the habit of chewing areca nut and tobacco $(\mathrm{OR}=1.600 ; \mathrm{p}=0.542)$, the duration of betel quid chewing more than 25 years $(\mathrm{OR}=4.379 ; \mathrm{p}=0.023)$, and the frequency of betel quid chewing more than 6 times/day $(\mathrm{OR}=4.800 ; \mathrm{p}=0.021)$. In conclusion, oral potentially malignant disorders were associated with chewing betel quid habit in the society of Samosir Island, North Sumatra, Indonesia.
\end{abstract}

Keywords: Oral potentially malignant disorders, oral submucous fibrosis, oral leukoplakia, betel quid chewing

\begin{abstract}
Abstrak
Kelainan mukosa mulut berpotensi maligna telah dihubungkan dengan kebiasaan menyirih. Sampai saat ini, menyirih masih berperan besar dalam aspek sosial dan budaya pada masyarakat di Pulau Samosir, Sumatera Utara Indonesia. Penelitian ini dilakukan untuk mengevaluasi terjadinya kelainan mukosa mulut berpotensi maligna yang dihubungkan dengan kebiasaan menyirih pada masyarakat di Pulau Samosir Sumatera Utara Indonesia. Penelitian kasus kontrol ini dilakukan pada seluruh penyirih di wilayah kerja Puskesmas Ambarita Kabupaten Samosir, Provinsi Sumatera Utara Indonesia. Pengumpulan data dilakukan dengan melakukan pemeriksaan rongga mulut dan pengisian kuesioner mengenai riwayat menyirih. Hubungan antara variabel dianalisis dengan Chi- square test dan Fisher's exact test. Hasil penelitian ini menunjukkan bahwa dari 51 orang penyirih, sebanyak 28 orang menunjukkan kelainan mukosa mulut berpotensi maligna, baik submukus fibrosis dan/atau leukoplakia (kelompok kasus), sementara itu 23 orang tidak menunjukkan kelainan mukosa mulut berpotensi maligna (kelompok kontrol). Peningkatan risiko kelainan mukosa mulut berpotensi maligna dapat dihubungkan dengan menyirih pinang dan tembakau $(\mathrm{OR}=1,600 ; \mathrm{p}=0,542)$, lama menyirih $>25$ tahun $(\mathrm{OR}=4,379 ; \mathrm{p}=0,023)$ dan jumlah menyirih $>6$ kali/hari $(\mathrm{OR}=4,800 ; \mathrm{p}=0,021)$. Sebagai kesimpulan, kelainan mukosa mulut berpotensi maligna dapat dihubungkan dengan kebiasaan menyirih yang dilakukan oleh masyarakat di Pulau Samosir Sumatera Utara Indonesia.
\end{abstract}

Kata kunci: Kelainan mukosa mulut berpotensi malignan, submucous fibrosis oral, leukoplakia oral, menyirih 


\section{INTRODUCTION}

Since 2005, The World Health Organization (WHO) Collaborating Centre for Oral Cancer and Precancer has recommended the use of the term "potentially malignant disorders" to describe lesions and precancerous conditions. The oral mucosal disorders included in the classification of the term consist of erythroplakia, actinic keratosis, lichen planus, discoid lupus erythematosus, leukoplakia, and submucous fibrosis. ${ }^{1}$ The risk of malignant transformation of these oral mucosal disorders has been reported at $0.13 \%-95.0 \% .^{24}$

In Asia, the development and onset of oral cancer or oral potentially malignant disorders are often associated with the betel quid chewing habit. ${ }^{5-7}$ In Indonesia, the local community commonly placed the finely cut tobacco clumps into the labial commissure after they did betel quid chewing for several minutes. This activity is named as menyuntil. $^{7}$ All of these activities can cause the formation of carcinogenic chemical compounds which are divided into three categories. Chewing areca nut without tobacco is classified into group 1 carcinogens while chewing tobacco without areca nut is classified into group 2 carcinogens. Chewing areca nut with tobacco is classified into group 3 carcinogens. ${ }^{8}$ In addition to the effects of chemical carcinogens, chewing betel quid can also cause a persistent irritant effect on the oral mucosa. ${ }^{7}$

Previous studies have found that betel quid chewers in Indonesia showed lichen planus (17.3\%), submucous fibrosis (9.6\%), and leukoplakia (9.1\%). ${ }^{6}$ A research which was conducted on residents of Tanah Karo Regency, North Sumatra, Indonesia found that $64.3 \%$ of the betel chewers showed oral mucosal disorders including submucous fibrosis $(21.4 \%)$ and leukoplakia (7.1\%). ${ }^{9}$ Differences in the culture and demography can lead to the emergence of variations in the compositions and ways of chewing betel quid in both communities and individuals in some regions. ${ }^{6,10}$ Thus, it might influence the development of oral mucosal disorders associated with betel quid chewing. ${ }^{6}$

Samosir is one of the regencies in North Sumatra of Indonesia where betel quid chewing still plays a major role in the social and cultural aspects of the society. However, comprehensive data on the characteristics of betel quid chewing and oral mucosal disorders in the local community are still limited to date. Therefore, this study was conducted to evaluate oral potentially malignant disorders associated with betel quid chewing habit of people in the Samosir Island, North Sumatra.

\section{MATERIALS AND METHODS}

This observational study with a case-control design was conducted in betel quid chewers community in the working area of Ambarita Public Health Center at Raya Ambarita Street, Ambarita Village, Simanindo Sub-district, Samosir Regency, North Sumatra. The case group consisted of subjects who had oral potentially malignant disorders such as leukoplakia and/or submucous fibrosis whereas the control group consisted of subjects who did not have oral potentially malignant disorders. The subjects were recruited using a consecutive sampling, one of the non-probability sampling types. The betel quid chewers in this study were defined as subjects who did betel quid chewing daily with a minimum of 6 months of chewing until this research data was collected. The subjects who had a habit of chewing betel quid along with smoking and drinking alcohol were excluded from this study.

This study has received approval of health research implementation from the Health Research Ethics Commission of Medical Faculty in the University of Sumatera Utara/ RSUP H. Adam Malik Medan No.498/TGL/KEPK FK USU-RSUP HAM/2016. Furthermore, subjects who voluntarily participated in the study were asked to sign an informed consent to participate in the research.

Data collection in this study included undergoing an oral soft tissues examination and answering questionnaires. The diagnosis of oral mucosal disorders was established clinically according to the criteria for the diagnosis of oral mucosal disorders in epidemiological studies. ${ }^{1,11}$ After that, subjects were asked to fill out questionnaires asking about their ways and history of chewing betel quid.

All research data were computerized. Normality of the data was tested with the Kolmogorov-Smirnov test while the relationship between variables was tested with the Chi-square test. The significance level used in this study was $\mathrm{p}<0.05$. 


\section{RESULTS}

The number of subjects in this study was 51 betel quid chewers. A total of 28 betel quid chewers who had oral potentially malignant disorders were assigned into the case group whereas a total of 23 betel quid chewers who did not have oral potentially malignant disorders were assigned into the control group. Table 1 shows the demographic characteristics of the research subjects. The results indicated that most of the subjects in both groups were above 63 years old, women, and elementary school graduate. Statistically, there were no

Table 1. The demographic characteristics of research subjects in the group of oral potentially malignant disorders and the control group differences in the age, gender, and level of education between the two groups.

The characteristics of oral mucosal disorders in both groups can be seen in Table 2. The types of oral potentially malignant disorders in the case group were submucous fibrosis $(50.0 \%)$, leukoplakia $(10.7 \%)$, and more than one potentially malignant disorders $(39.3 \%)$. In both groups, there was a statistically significant difference in the types of oral mucosal disorders $(\mathrm{p}<0.005)$.

\begin{tabular}{|c|c|c|c|c|c|c|}
\hline \multicolumn{2}{|c|}{ Demographic characteristics } & \multicolumn{2}{|c|}{$\begin{array}{c}\text { Potentially malignant } \\
\text { disorders } \\
\text { (Case) } \\
\mathbf{n = 2 8} \\
\end{array}$} & \multicolumn{2}{|c|}{$\begin{array}{c}\text { No potentially } \\
\text { malignant disorders } \\
\text { (Control) } \\
n=23\end{array}$} & \multirow[t]{2}{*}{ p-value } \\
\hline & & $\mathbf{n}$ & $\%$ & $\mathbf{n}$ & $\%$ & \\
\hline \multirow[t]{2}{*}{ Age $^{a)}$} & $>63$ years & 18 & 64.3 & 9 & 39.1 & 0.095 \\
\hline & $\leq 63$ years & 10 & 35.7 & 14 & 60.9 & \\
\hline Gender & Female & 28 & 100.0 & 23 & 100.0 & \\
\hline \multirow[t]{4}{*}{ Education $^{\text {b) }}$} & No School & 10 & 35.7 & 7 & 30.4 & 0.710 \\
\hline & Elementary School & 15 & 53.6 & 9 & 39.1 & \\
\hline & Junior High School & 2 & 7.1 & 4 & 17.4 & \\
\hline & Senior High School & 1 & 3.6 & 3 & 13.0 & \\
\hline
\end{tabular}

Table 2. The characteristics of the oral potentially malignant disorders types in the case group and the control group

\begin{tabular}{lccccc}
\hline & \multicolumn{2}{c}{$\begin{array}{c}\text { Potentially malignant } \\
\text { disorders } \\
\text { (Case) } \\
\mathbf{n = 2 8}\end{array}$} & $\begin{array}{c}\text { No potentially } \\
\text { malignant disorders } \\
\text { (Control) } \\
\mathbf{n = 2 3}\end{array}$ & p-value \\
\cline { 2 - 5 } & $\mathbf{n}$ & $\mathbf{\%}$ & $\mathbf{n}$ & $\mathbf{\%}$ & \\
\hline Submucous fibrosis & 14 & 50.0 & 0 & 0.0 & $0.000^{*}$ \\
Leukoplakia & 3 & 10.7 & 0 & 0.0 & \\
$>$ 1 potentially malignant disorders & 11 & 39.3 & 0 & 0.0 & \\
No potentially malignant disorders & 0 & 0.0 & 23 & 100.0 & \\
\end{tabular}


Table 3 depicts the characteristics of betel quid chewing in the case and control group. As shown, the research subjects mostly chewed both areca nut and tobacco in which $75 \%$ of subjects in the case group and $62.5 \%$ of subjects in the control group. In addition, most of the subjects in both groups $(92.9 \%$ in the case group and $82.6 \%$ in the control group) added slaked-lime and gambier to the quid mixture and subsequently wrapped it in the betel leaves. Most of the subjects in both groups also continued the betel quid chewing activity to menyuntil with $85.7 \%$ of subjects in the case group and $65.2 \%$ of subjects in the control group. Statistically, there were no differences in the main ingredients $(\mathrm{p}=1.000)$, additional ingredients $(\mathrm{p}=1.000)$, activity after betel quid chewing $(\mathrm{p}=0.154)$, menyuntil activity

Table 3. The characteristics of betel quid chewing history in the oral potentially malignant disorders (the case group) and the control group $(\mathrm{p}=0.107)$, activity of cleaning the oral cavity $(\mathrm{p}=0.915)$, and activity of examining the oral cavity to the Public Health Centre $(\mathrm{p}=0.442)$ between the case group and the control group.

The relationship between the main ingredients, the duration of betel quid chewing in years, and the frequency of betel quid chewing per day with oral potentially malignant disorders can be seen in Table 4. An increased risk of oral potentially malignant disorders can be associated with areca nut and tobacco chewing $(\mathrm{OR}=1.600 ; \mathrm{p}=0.542)$, the duration of betel quid chewing above 25 years $(\mathrm{OR}=4.379$; $\mathrm{p}=0.023$ ), and the frequency of betel quid chewing more than 6 times/day $(\mathrm{OR}=4.800 ; \mathrm{p}=0.021)$.

\begin{tabular}{|c|c|c|c|c|c|c|}
\hline \multicolumn{2}{|c|}{ Betel quid chewing history } & \multicolumn{2}{|c|}{$\begin{array}{c}\text { Potentially } \\
\text { malignant disorders } \\
\text { (Case) } \\
\mathbf{n = 2 8}\end{array}$} & \multicolumn{2}{|c|}{$\begin{array}{c}\text { No potentially } \\
\text { malignant } \\
\text { disorders (Control) } \\
n=23\end{array}$} & \multirow[t]{2}{*}{$\begin{array}{c}\text { p- } \\
\text { value }\end{array}$} \\
\hline & & $\mathbf{n}$ & $\%$ & $\mathbf{n}$ & $\%$ & \\
\hline \multirow[t]{3}{*}{$\begin{array}{l}\text { Main } \\
\text { ingredients a) }\end{array}$} & $\begin{array}{l}\text { Areca nut and } \\
\text { tobacco }\end{array}$ & 21 & 75.0 & 15 & 65.2 & \multirow[t]{3}{*}{$\begin{array}{l}1.0 \\
00\end{array}$} \\
\hline & Only areca nut & 6 & 21.4 & 8 & 34.8 & \\
\hline & Only tobacco & 1 & 3.6 & 0 & 0.0 & \\
\hline \multirow{4}{*}{$\begin{array}{r}\text { Additional } \\
\text { ingredients }\end{array}$} & $\begin{array}{l}\text { Betel leaves, slaked } \\
\text { lime }\end{array}$ & 0 & 0.0 & 1 & 4.3 & \multirow[t]{4}{*}{$\begin{array}{l}1.0 \\
00\end{array}$} \\
\hline & $\begin{array}{l}\text { Betel leaves, slaked } \\
\text { lime gambier } \\
\text { Betel leaves, slaked }\end{array}$ & 26 & 92.9 & 19 & 82.6 & \\
\hline & $\begin{array}{l}\text { lime, gambier, and } \\
\text { candlenut }\end{array}$ & 0 & 0.0 & 2 & 8.7 & \\
\hline & Only betel leaves & 2 & 7.1 & 1 & 4.3 & \\
\hline \multirow{2}{*}{$\begin{array}{l}\text { Acitivity done } \\
\text { after the betel } \\
\text { quid was chewed } \\
\text { b) }\end{array}$} & Swallowed & 3 & 10.7 & 7 & 30.4 & \multirow{2}{*}{$\begin{array}{l}0.1 \\
54\end{array}$} \\
\hline & $\begin{array}{l}\text { Thrown away/spat } \\
\text { out }\end{array}$ & 25 & 89.3 & 16 & 69.6 & \\
\hline \multirow{2}{*}{$\begin{array}{l}\text { Menyuntil } \\
\text { activity }{ }^{\text {b) }}\end{array}$} & Present & 24 & 85.7 & 15 & 65.2 & \multirow[t]{2}{*}{$\begin{array}{l}0.1 \\
07\end{array}$} \\
\hline & Not present & 4 & 14.3 & 8 & 34.8 & \\
\hline
\end{tabular}




\begin{tabular}{|c|c|c|c|c|c|c|}
\hline Activity of & Use tobacco & 1 & 3.6 & 0 & 0.0 & 0.9 \\
\hline & $\begin{array}{l}\text { Use the rind of } \\
\text { areca nut }\end{array}$ & 4 & 14.3 & 3 & 13.0 & \\
\hline & Rinse with water & 18 & 64.3 & 12 & 52.2 & \\
\hline & Brush the teeth & 2 & 7.1 & 6 & 26.1 & \\
\hline & None & 3 & 10.7 & 2 & 8.7 & \\
\hline $\begin{array}{l}\text { Activity of } \\
\text { examining the } \\
\text { oral cavity health }\end{array}$ & $\begin{array}{l}\text { If there is a } \\
\text { complaint of } \\
\text { pain/sick }\end{array}$ & 3 & 10.7 & 5 & 21.7 & $\begin{array}{l}0.4 \\
42\end{array}$ \\
\hline & Never & 25 & 89.3 & 18 & 78.3 & \\
\hline
\end{tabular}

\section{a) Two-sample Kolmogorov-Smirnov test}

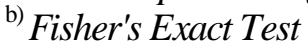

Table 4. The relationship between the main ingredients, duration (year), and the total number (day) of chewing betel quid with oral potentially malignant disorders

\begin{tabular}{|c|c|c|c|c|c|c|c|c|c|}
\hline & & \multicolumn{2}{|c|}{$\begin{array}{c}\text { Potentially } \\
\text { malignant } \\
\text { disorders } \\
\text { (Case) } \\
\text { n= 28 }\end{array}$} & \multicolumn{2}{|c|}{$\begin{array}{c}\text { No } \\
\text { potentially } \\
\text { malignant } \\
\text { disorders } \\
\text { (Control) } \\
\text { n= 23 } \\
\end{array}$} & \multirow[t]{2}{*}{$\begin{array}{c}\text { p- } \\
\text { value }\end{array}$} & \multirow[t]{2}{*}{ OR } & \multicolumn{2}{|c|}{ CI 95\% } \\
\hline & & $\mathbf{n}$ & $\%$ & $\mathbf{n}$ & $\%$ & & & $\begin{array}{l}\text { Mi } \\
\text { n }\end{array}$ & Max \\
\hline \multirow{2}{*}{$\begin{array}{c}\text { Main } \\
\text { ingredients }\end{array}$} & Areca nut & 21 & 75.0 & 15 & 65.2 & \multirow[t]{2}{*}{0.542} & \multirow{2}{*}{$\begin{array}{l}1.6 \\
00\end{array}$} & \multirow{2}{*}{$\begin{array}{l}0.4 \\
76\end{array}$} & \multirow[t]{2}{*}{5.374} \\
\hline & $\begin{array}{l}\text { and tobacco } \\
\text { Only areca } \\
\text { nut or only } \\
\text { tobacco }\end{array}$ & 7 & 25.0 & 8 & 34.8 & & & & \\
\hline \multirow[t]{2}{*}{ Duration } & $>25$ years & 17 & 60.7 & 6 & 26.1 & \multirow[t]{2}{*}{$\begin{array}{c}0.023 \\
*\end{array}$} & \multirow{2}{*}{$\begin{array}{l}4.3 \\
79\end{array}$} & \multirow{2}{*}{$\begin{array}{l}1.3 \\
18\end{array}$} & \multirow{2}{*}{$\begin{array}{c}14.54 \\
7\end{array}$} \\
\hline & $\leq 25$ years & 11 & 39.3 & 17 & 73.9 & & & & \\
\hline \multirow{2}{*}{$\begin{array}{l}\text { Frequenc } \\
\mathrm{y}\end{array}$} & $>6$ & 16 & 57.1 & 5 & 21.7 & \multirow{2}{*}{$\begin{array}{c}0.021 \\
*\end{array}$} & \multirow{2}{*}{$\begin{array}{l}4.8 \\
00\end{array}$} & \multirow{2}{*}{$\begin{array}{l}1.3 \\
87\end{array}$} & \multirow{2}{*}{$\begin{array}{c}16.61 \\
6\end{array}$} \\
\hline & $\begin{array}{l}\text { times/day } \\
\leq 6 \\
\text { times/day }\end{array}$ & 12 & 42.9 & 18 & 78.3 & & & & \\
\hline
\end{tabular}

Fisher's exact test

${ }^{*} \mathrm{p}<0.05=$ significant 


\section{DISCUSSION}

The demographic characteristics of the research subjects are consistent with the previous study in six Asian countries suggesting that the prevalence of betel quid chewers in Indonesia is more prevalent in the older age group (above 40 years old). In contrast, betel quid chewers in other countries were mostly found in the younger age group (under 40 years old) because it is more interesting and easier to get chewing products in a commercial form as the advertisement of the chewing products increases in their country. ${ }^{6}$ In addition, Indonesian men prefer a more practical way of using tobacco (i.e. smoking); thus, betel quid chewing is more commonly found in women. On the other side, subjects with low education were generally less concerned with the risk of chewing betel quid on their health. ${ }^{6}$ The demographic data of this study indicate the similarity of the average age, gender, and education between the two observation groups. Thus, this study was expected to show a generalization of the research results. $^{12}$

Among 51 research subjects, 28 subjects had oral potentially malignant disorders consisting of submucous fibrosis, leukoplakia, or both as the case group, whereas 23 subjects did not have oral potentially malignant disorders as the control group. The results of this study are consistent with several previous studies that evaluated the occurrence of oral mucosa disorders in betel quid chewers. ${ }^{6,9,13-15}$ In 2004, the IARC has determined that the betel quid chewing habit are the risk factor that may have a role in the onset and development of oral cancer. In addition, several studies have demonstrated the malignant transformation of submucous fibrosis ${ }^{4}$ and leukoplakia. ${ }^{1,} \quad 4, \quad 16-18$ The risk of malignant transformation of an oral potentially malignant disorders was found to increase in both betel quid chewers and smokers in Taiwan. ${ }^{3}$

Diagnosis of oral potentially malignant disorders in this study was based on clinical features in accordance with the terminology and nomenclature set by WHO Collaborating Centre for Oral Cancer and Precancer in 2005. ${ }^{1}$ Based on the clinical description ${ }^{1}$, the cases of submucous fibrosis in this study were found in the early and advanced stages. On the other hand, based on the clinical type ${ }^{1}$, leukoplakia cases in this study generally showed a homogeneous type, and only one case showed a nonhomogeneous type. However, this study has not performed the histopathologic examination for the diagnosis of oral potentially malignant disorders so that definitive diagnosis cannot be established. The findings of oral mucosa conditions and lesions in the subjects may indicate that the subjects had a lack of awareness about the symptoms and signs of changes in their oral cavity and a lack of awareness to report and undergo treatment for such changes at the local public health facility. The results showed that $89.3 \%$ of subjects in the case group and $78.3 \%$ of subjects in the control group stated that they have never checked their oral cavity health before in the public health center.

The difference in the betel quid composition and the dose-response relationship in the research subjects may affect the study results about oral mucosa disorders associated with betel quid chewing. ${ }^{7}$ This study result differs from some previous studies which suggest that betel quid chewers in Indonesia tend not to include tobacco in its quid composition. ${ }^{6,7,9}$ In contrast, most of the subjects in this study made a quid composition consisting of areca nut and tobacco added with slaked lime and gambier, and then it was wrapped in betel leaves and chewed for some time. The study results showed that most subjects placed the finely cut tobacco clumps into the labial commissure after they did betel quid chewing for several minutes. In the local community, this activity is named as menyuntil. This result was different from those of previous studies which found that most of the subjects in Tanah Karo Indonesia did not do menyuntil or placed tobacco clumps between gingiva/teeth and buccal mucosa for a long time after the betel quid chewing activity. ${ }^{9}$

The IARC in 2004 claimed that there was sufficient evidence to show the carcinogenic effects of betel quid chewing using tobacco and areca nut in humans. Betel quid chewers may be exposed to chemical carcinogenic compounds, both tobaccospecific nitrosamines (TSNA) and areca-nut-derived nitrosamines. ${ }^{19}$ In addition, betel quid chewing will also produce reactive oxygen species (ROS) formed by auto-oxidation of polyphenols contained in areca nut and gambier, under alkaline $\mathrm{pH}$ conditions produced by lime. The ROS produced and released in the oral mucosa can be directly involved in the initiation process of the tumor because the compound can induce genetic damage to oral mucosal epithelial cells. Moreover, the ROS may also invade salivary and oral mucosal proteins which will then facilitate the penetration of the betel quid 
chewing composition and foreign objects present in the oral environment. ${ }^{7}, 19$

Local irritation and trauma that occur continuously from betel quid chewing can cause chronic inflammation, oxidative stress, and cytokine production. In vitro, morphological changes and cell membrane damage can be found due to the adhesive properties of areca nut particles in oral mucosal culture cells. Oxidative stress and ROS formation can affect cell proliferation and cell death. When such conditions occur chronically, hyperplasia of dysplasia lesions may be formed inside the oral cavity that may progress into preneoplasia and even malignant lesions.?

The study found that the risk of oral potentially malignant disorders increased if the duration of betel quid chewing and the frequency of betel quid chewing per day increased. This result was consistent with previous studies. ${ }^{7,9,14,20}$ The IARC has observed a dose-response relationship from the frequency of betel quid chewing per day (by unit times per day) and duration of betel quid chewing (by unit years) with an increased risk of the occurrence of oral potentially malignant disorders. The risk of occurrence of oral potentially malignant disorders will also increase in the subjects who allowed the quid stayed in their mouth throughout the night.

\section{REFERENCES}

1. Warnakulasuriya S, Johnson NW, Van Der Wall I. Review article: Nomenclature and classification of potentially malignant disorders of the oral mucosa. J Oral Pathol Med 2007; 36: 575-80.

2. Warnakulasuriya S, Ariyawardana A. Malignant transformation of oral leukoplakia: a systematic review of observational studies. J Oral Pathol Med 2016; 45: 155-166.

3. Yen AMF, Chen SC, Chang SH, Chen THH. The effect of betel quid and cigarette on multistate progression of oral pre-malignancy. J Oral Pathol Med 2008; 37: 417-422.

4. Hsue SS, Wang WC, Chen $\mathrm{CH}$, Lin $\mathrm{CC}$, Chen YK, Lin LM. Malignant transformation in 1458 patients with potentially malignant oral mucosal disorders: A follow-up study based in a Taiwanese hospital. J Oral Pathol Med 2007; 36: 25-9.

5. Priebe SL, Aleksejuniene J, Dharamsi S, Zed C. Oral cancer and cultural factors in Asia. Can J Dent Hygiene 2008; 42 (6): 289-293.

6. Lee, CH, Ko AMS, Warnakulasuriya S, Yin BL., Sunarjo, Zain RB, dkk. Intercountry prevalences and practices of betel-quid use in south, southeast
In conclusion, the risk of oral potentially malignant disorders increased in the community of betel quid chewers in Samosir Island, North Sumatra, particularly those people who used areca nut and tobacco in their quid. The increased risk of occurrence of such disorders may also be related to the increase in the duration of betel quid chewing and the frequency of betel quid chewing per day. The local Health Office which is the Health Office of Samosir Regency in North Sumatra should immediately design a health program as an effort to promote health and screening so that they can evaluate and prevent the development of oral potentially malignant disorders related to betel quid chewing.

\section{ACKNOWLEDGEMENTS}

The following experts for providing helpful comments and advices on the present study: Gus Permana Subita, drg., Sp.PM., Ph.D; Prof. Dr. Syafruddin Ilyas, M.Biomed; and H. Delyuzar, dr., M.Ked(PA)., Sp.PA(K). The following staff of local public health office in regency of Samosir, province of North Sumatra, Indonesia for contributed greatly to this study: dr. Managam Togatorop; Daulat Nainggolan, SKM., M.Kes; Netty Tobing, drg; and Doar Siregar, drg and eastern Asia regions and associated oral preneoplastic disorders: an international collaborative study by Asian betel-quid consortium of south and east Asia. Int J Cancer 2011; 129: $1741-1751$

7. IARC, 2004. IARC monographs on the evaluation of carcinogenic risks to humans: Betel-quid and areca-nut chewing and some areca-nut derived nitrosamines, 85: Lyon, France. 1-334.

8. Patidar KA, Parwani R, Wanjari SP, Patidar AP. Various terminologies associated with areca nut and tobacco chewing: A review. J Oral Maxillofac Pathol 2015; 19: 69-76.

9. Hasibuan S, Permana G, Aliyah S. Lesi-lesi mukosa mulut yang dihubungkan dengan kebiasaan menyirih di kalangan penduduk Tanah Karo, Sumatera Utara. Dentika Dent J 2003; 8 (2): 67-74.

10. Sharan RN, Mehrotra R, Choudhury Y, Asotra K. Association of Betel Nut with Carcinogenesis: Revisit with a Clinical Perspective. PLoS ONE 2012; 7(8): e42759. 
11. World Health Organization. Oral health surveys: Basic methods, $5^{\text {th }}$ ed. World Health Organization 2013; ISBN 978-92-4-154864-9: 53-55.

12. Sastroasmoro S. Pemilihan subyek penelitian, dalam Sastroasmoro, S; Ismael, S. Dasar-dasar metodologi penelitian klinis, $4^{\text {rd }}$ ed, Jakarta: Sagung Seto. 2011: 99, 308.

13. Ariyawardana A, Sitheeque MAM, Ranasinghe AW, Perera I, Tilakaratne WM, Amaratunga APD, Yang YH, Warnakulasuriya S. Prevalence of oral cancer and pre-cancer and associated risk factors among tea estate workers in the central Sri Lanka. Oral Pathol Med 2007; 36: 581-7.

14. Behura SS, Masthan MK, Narayanasamy AB. Oral mucosal lesions associated with smokers and chewers - A case-control: Study in Chennai population. Journal of Clinical and Diagnostic Research 2015; 9 (7): ZC17-ZC22.

15. Vikneshan M, Ankola AV, Hebbal M, Sharma R, Suganya M. Patterns of tobacco usage and oral mucosal lesions of industrial workers: A cross sectional study. Austin J Public Health Epidemiol 2016; 3(1): 1029.
16. Liu W, Xue-Min Shen XM, Liu Y, Li J, Zhou ZT, Wang LZ. Malignant transformation of oral verrucous leukoplakia: a clinicopathologic study of 53 cases 2011; 40: 312-316.

17. Brouns EREA, Baart JA, Karagozoglu KH, Aartman IHA, Bloemena E, Van der Waal I. Malignant transformation of oral leukoplakia in a well-defined cohort of 144 patients. Oral Diseases 2014; 20: e19-e24.

18. Narayan TV, Shilpashree S. Meta-analysis on clinicopathologic risk factors of leukoplakias undergoing malignant transformation. J Oral Maxillofac Pathol 2016; 20: 354-61.

19. Mehrotra R, Yadav S. Oral squamous cell carcinoma: Etiology, pathogenesis, and prognostic value of genomic alterations. Indian J Cancer 2006; 43 (2): 60-65.

20. Joshi M, Tailor M. Prevalence of most commonly reported tobacco-associated lesions in central Gujarat: A hospital-based cross-sectional study. Indian J Dent Res 2016; 27: 405-9. 